\title{
Computing Bottom-Up Betas For Companies In The Soft Drink Industry
}

\author{
V. Reddy Dondeti, Norfolk State University, USA \\ Carl B. McGowan, Jr., Norfolk State University, USA \\ Susan E. Moeller, Eastern Michigan University, USA
}

\begin{abstract}
In this paper, we decompose the CAPM equity beta for Coca-Cola and Pepsi (KOPEP) to show the industry component and the operating leverage and the financial leverage components for the period from 2004 to 2012. We compute the CAPM equity betas using a standard five year, sixty month, regression between returns for KOPEP using the $S \& P 500$ as the market index. We adjust for financial leverage using the Hamada (1969) methodology and we adjust for operating leverage using the degree of operating leverage (DOL). The average business beta for Coca-Cola is 0.1882 and the average business beta for Pepsico is 0.1369. Over the period of this analysis, Coca-Cola has had a business beta slightly higher than the business beta for Pepsico.
\end{abstract}

Keywords: CAPM; Bottom-Up Beta; Equity Beta; Unlevered Beta; Business Beta; Coca-Cola; Pepsi

\section{INTRODUCTION}

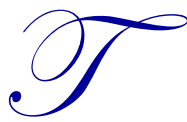

he objective of corporate financial management is to maximize the value of the firm. The value of the firm is the market value of the firm determined by multiplying the number of shares outstanding times the price per share. The price of a share of stock in a corporation is the discounted present value of the future cash flows from the share including dividends and capital gains. Estimates of the future cash flows are based on the concept of free cash flow to equity such as developed in Damodaran (2006). Brigham and Ehrhardt (2008, pp. 287-288) and Ross, Westerfield, and Jordan (2008, pp. 235-238) both develop similar models for dividends. The required rate of return on the stock in a company is determined by the riskiness of the company's future cash flows. The volatility of future cash flows is influenced by the industry in which the company functions, the degree of operating leverage which measures the extent to which the company uses fixed cost assets, and the degree of financial leverage which measures the extent to which the company uses fixed cost financing. The objective of this paper is to decompose the market determined beta coefficient for the company into the industry component, the operating leverage component, and the financial leverage component for a sample of companies in the soft drink industry, specifically KOPEP.

Modern Portfolio Theory originated in Markowitz (1952) which showed how to determine the optimal set of efficient portfolios available for selection by investors. The CAPM (market) beta is derived from Sharpe (1963, 1964). Sharpe $(1963,1964)$ develops an asset pricing model for securities based on market risk only. The market beta is the regression coefficient of the characteristic line for the stock. The characteristic line is derived from the regression between the excess return on a specific stock for a period and the excess return on the stock market index. Gardner, McGowan, and Moeller (2010) show how to compute the beta coefficient for Coca-Cola and Harper, Jordan, McGowan, and Revello (2010) show how to collect data and compute the beta coefficient for DOW Chemical Corporation. Usually, beta is computed using five years of monthly returns data or sixty observations as in SBBI (2010, p. 69).

$R_{e}=R_{f}+\beta_{A}\left(R_{m}-R_{f}\right)$

where, 
$\mathrm{R}_{\mathrm{e}} \quad=$ the estimated cost of equity for the firm

$\mathrm{R}_{\mathrm{f}} \quad=$ the risk free rate of return

$\mathrm{R}_{\mathrm{m}} \quad=$ the return on the market (S\&P500)

$\beta_{\mathrm{A}} \quad=$ beta of the firm

$\left(\mathrm{R}_{\mathrm{m}}-\mathrm{R}_{\mathrm{f}}\right)=$ the market risk premium

2010 Ibbotson Stocks, Bonds, Bills, and Inflation Valuation Yearbook (SBBI, 2010, p. 70, Table 6-1) reports that beta regression coefficients for excess returns are the same as beta regression coefficients for total returns using five years of monthly data. The S\&P500 is used as the proxy for the stock market. SBBI (2010, p. 71, Table 6-2) reports that the correlation coefficient between the S\&P 500 and the NYSE, NYSE/AMEX, and NYSE/AMEX/NASDAQ indexes are all 1.00 and that "Because of this high correlation, the ultimate market proxy chosen has only a minor impact on the beta calculation." SBBI (2010, p. 71, Table 6-3) shows that company betas for a group of ten large companies have correlation coefficients of 0.99 to 1.00. The SBBI betas are calculated using monthly excess returns for October 2004 to September 2009.

\section{DERIVING THE BUSINESS BETA FOR A FIRM}

Bottom-up betas are used to compute industry betas adjusting equity betas for both financial leverage and for operating leverage. The equity beta coefficient, $\boldsymbol{\beta}_{\text {equity }}$, for a firm is influenced by the industry, by operating leverage and by financial leverage. We adjust for financial leverage using the Hamada (1969) methodology and we adjust for operating leverage using the degree of operating leverage. The business beta is the systematic risk measure for the industry in which the firm operates.

$\beta_{\text {equity }}=\mathrm{f}($ business risk, operating risk, financial risk)

The business beta should be similar for Coca-Cola and Pepsi because they are essentially in the same industry.

The Hamada (1969) formula for showing the impact on beta of increasing financial leverage is

$\beta_{\text {equity }}=[1+(1-\mathrm{Tc})(\mathrm{D} / \mathrm{E})]^{*} \beta_{\text {unlevered }}$

where,

$\beta_{\text {equity }}=$ the beta coefficient adjusted for financial leverage

$\beta_{\text {unlevered }}=$ the beta coefficient with no financial leverage

$\mathrm{Tc} \quad=$ the marginal tax rate

$\mathrm{D}=$ the market value of debt

$\mathrm{E} \quad=$ the market value of equity

$\mathrm{D} / \mathrm{E} \quad=$ the debt to equity ratio

Solving for the unlevered beta for a company yields

$\beta_{\text {unlevered }}=\beta_{\text {equity }} /[1+(1-\mathrm{Tc})(\mathrm{D} / \mathrm{E})]$

The unlevered beta can be adjusted for operating leverage using the degree of operating leverage.

$\beta_{\text {unlevered }}=[(1+\mathrm{DOL})] * \beta_{\text {business }}$

where,

$\beta_{\text {unlevered }}=$ the beta coefficient with no financial leverage

$\beta_{\text {business }}=$ the beta coefficient adjusted for operating leverage

DOL $=$ the degree of operating leverage 
The business beta is the unlevered beta adjusted for financial leverage divided by one plus the DOL.

$\beta_{\text {business }}=\beta_{\text {unlevered }} /[(1+\mathrm{DOL})]$

The business beta for a firm is adjusted for both financial leverage and operating leverage. The business beta is the beta for a company that should reflect the risk of operating in the particular industry. The market risk beta will include the effects of the industry as well as the extent that the firm uses operating leverage and financial leverage. Substituting the value of the unlevered (financial risk) beta in Equation [5] into the value of the equity beta in Equation [3] yields the three constituent components of the equity beta. The equity beta is the business beta multiplied by the adjustment factor for financial leverage times the adjustment factor for operating leverage.

$\beta_{\text {equity }}=[1+(1-\mathrm{Tc})(\mathrm{D} / \mathrm{E})]^{*}[(1+\mathrm{DOL})] * \beta_{\text {business }}$

Business beta is the equity beta divided by the financial risk factor and the operating risk factor.

$\beta_{\text {business }}=\beta_{\text {equity }} /[1+(1-\mathrm{Tc})(\mathrm{D} / \mathrm{E})] *[(1+\mathrm{DOL})]$

Thus, we can determine the business risk factor by dividing the market risk beta by the financial leverage effect and by the operating leverage effect.

\section{EMPIRICAL RESULTS}

Table 1 shows the results of computing the business beta for Coca-Cola for the period from 2004 to 2012 . The top panel of Table 1 contains the input data needed to compute the business beta for Coca-Cola: Total revenue, total assets, total owners' equity, total debt, operating income, and the tax rate. Panel 2 of Table 1 shows the computations needed to compute the business beta for Coca-Cola: the debt to equity ratio, one minus the tax rate, the unlevered beta divisor, the unlevered beta, the degree of operating leverage, and one plus the degree of operating leverage. The business beta for Coca-Cola is in the final row of Table 1. The average equity beta for Coca-Cola over the test period is 0.5824 and the average unlevered beta is 0.3384 . The average business beta for Coca-Cola is 0.1685 and ranges from 0.0739 to 0.2344 .

Table 2 provides the same computations for Pepsico for the period from 2004 to 2012. The top panel of Table 2 contains the input data needed to compute the business beta for Pepsico: Total revenue, total assets, total owners' equity, total debt, operating income, and the tax rate. Panel 2 of Table 2 shows the computations needed to compute the business beta for Pepsico: the debt to equity ratio, one minus the tax rate, the unlevered beta divisor, the unlevered beta, the degree of operating leverage, and one plus the degree of operating leverage. The business beta for Pepsico is in the final row of Table 2. The average equity beta for Pepsico over the test period is 0.5319 and the average unlevered beta is 0.2682 . The average business beta for Pepsico is 0.1329 and ranges for 0.1038 to 0.1900 . 


\begin{tabular}{|c|c|c|c|c|c|c|c|c|c|c|}
\hline KO & 2004 & 2005 & 2006 & 2007 & 2008 & 2009 & 2010 & 2011 & 2012 & Average \\
\hline Total Revenue & 21742 & 23104 & 24088 & 28857 & 31944 & 30900 & 35119 & 46542 & 48017 & 35067 \\
\hline Total Assets & 31441 & 29427 & 29963 & 43269 & 40519 & 48671 & 72921 & 79974 & 86174 & 57356 \\
\hline Total Equity & 15935 & 16355 & 16920 & 21744 & 20860 & 25346 & 31317 & 31921 & 33168 & 25897 \\
\hline Total Debt & 15506 & 13072 & 13043 & 21525 & 19659 & 23325 & 41604 & 48053 & 53006 & 31459 \\
\hline Operating Income & 5698 & 6085 & 6597 & 7520 & 8446 & 8231 & 8413 & 10173 & 10779 & 8594 \\
\hline Tax Rate & $35 \%$ & $35 \%$ & $35 \%$ & $35 \%$ & $35 \%$ & $35 \%$ & $35 \%$ & $35 \%$ & $35 \%$ & $35 \%$ \\
\hline $\mathrm{D} / \mathrm{E}$ & 0.9731 & 0.7993 & 0.7709 & 0.9899 & 0.9424 & 0.9203 & 1.3285 & 1.5054 & 1.5981 & 1.1508 \\
\hline Equity Beta & 0.2408 & 0.4952 & 0.4764 & 0.7648 & 0.5931 & 0.6108 & 0.5957 & 0.5322 & 0.5039 & 0.5824 \\
\hline (1-Tax Rate) & $65 \%$ & $65 \%$ & $65 \%$ & $65 \%$ & $65 \%$ & $65 \%$ & $65 \%$ & $65 \%$ & $65 \%$ & 0.6500 \\
\hline$(1+(1-t)(D / E)$ & 1.6325 & 1.5195 & 1.5011 & 1.6435 & 1.6126 & 1.5982 & 1.8635 & 1.9785 & 2.0388 & 1.7480 \\
\hline Unlevered Beta & 0.1475 & 0.3259 & 0.3174 & 0.4654 & 0.3678 & 0.3822 & 0.3197 & 0.2690 & 0.2472 & 0.3384 \\
\hline DOL & 0.9951 & 0.9617 & 1.0509 & 0.9856 & 0.9926 & 1.1120 & 1.0960 & 0.9737 & 0.8197 & 1.0043 \\
\hline$(1+\mathrm{DOL})$ & 1.9951 & 1.9617 & 2.0509 & 1.9856 & 1.9926 & 2.1120 & 2.0960 & 1.9737 & 1.8197 & 2.0043 \\
\hline Business Beta & 0.0739 & 0.1661 & 0.1548 & 0.2344 & 0.1846 & 0.1810 & 0.1525 & 0.1363 & 0.1358 & 0.1685 \\
\hline
\end{tabular}

Table 2

\begin{tabular}{|l|c|c|c|c|c|c|c|c|c|c|}
\hline \multicolumn{1}{|c|}{ PEP } & $\mathbf{2 0 0 4}$ & $\mathbf{2 0 0 5}$ & $\mathbf{2 0 0 6}$ & $\mathbf{2 0 0 7}$ & $\mathbf{2 0 0 8}$ & $\mathbf{2 0 0 9}$ & $\mathbf{2 0 1 0}$ & $\mathbf{2 0 1 1}$ & $\mathbf{2 0 1 2}$ & Average \\
\hline Total Revenue & 29261 & 32562 & 35137 & 39474 & 43251 & 43232 & 57838 & 66504 & 65492 & 50133 \\
\hline Total Assets & 27987 & 31727 & 29930 & 34628 & 35994 & 39848 & 68153 & 72882 & 74638 & 50868 \\
\hline Total Equity & 13523 & 14251 & 15368 & 17234 & 12106 & 17442 & 21476 & 28999 & 22399 & 19289 \\
\hline Total Debt & 14464 & 17476 & 14562 & 17394 & 23888 & 22406 & 46677 & 43883 & 52239 & 31578 \\
\hline Operating Income & 5409 & 5922 & 6506 & 7170 & 6935 & 8044 & 8332 & 9633 & 9112 & 7962 \\
\hline Tax Rate & $35 \%$ & $35 \%$ & $35 \%$ & $35 \%$ & $35 \%$ & $35 \%$ & $35 \%$ & $35 \%$ & $35 \%$ & $35 \%$ \\
\hline
\end{tabular}


Figure 1 shows the graphs of the business betas calculated from these empirical results. For 2005 and 2006 the betas are very similar. For the period from 2004 to 2012, Coca-Cola has a higher business beta than Pepsico. The correlation coefficient between the bottom-up betas for Coca-Cola and the bottom-up betas for Pepsi is 0.3091.

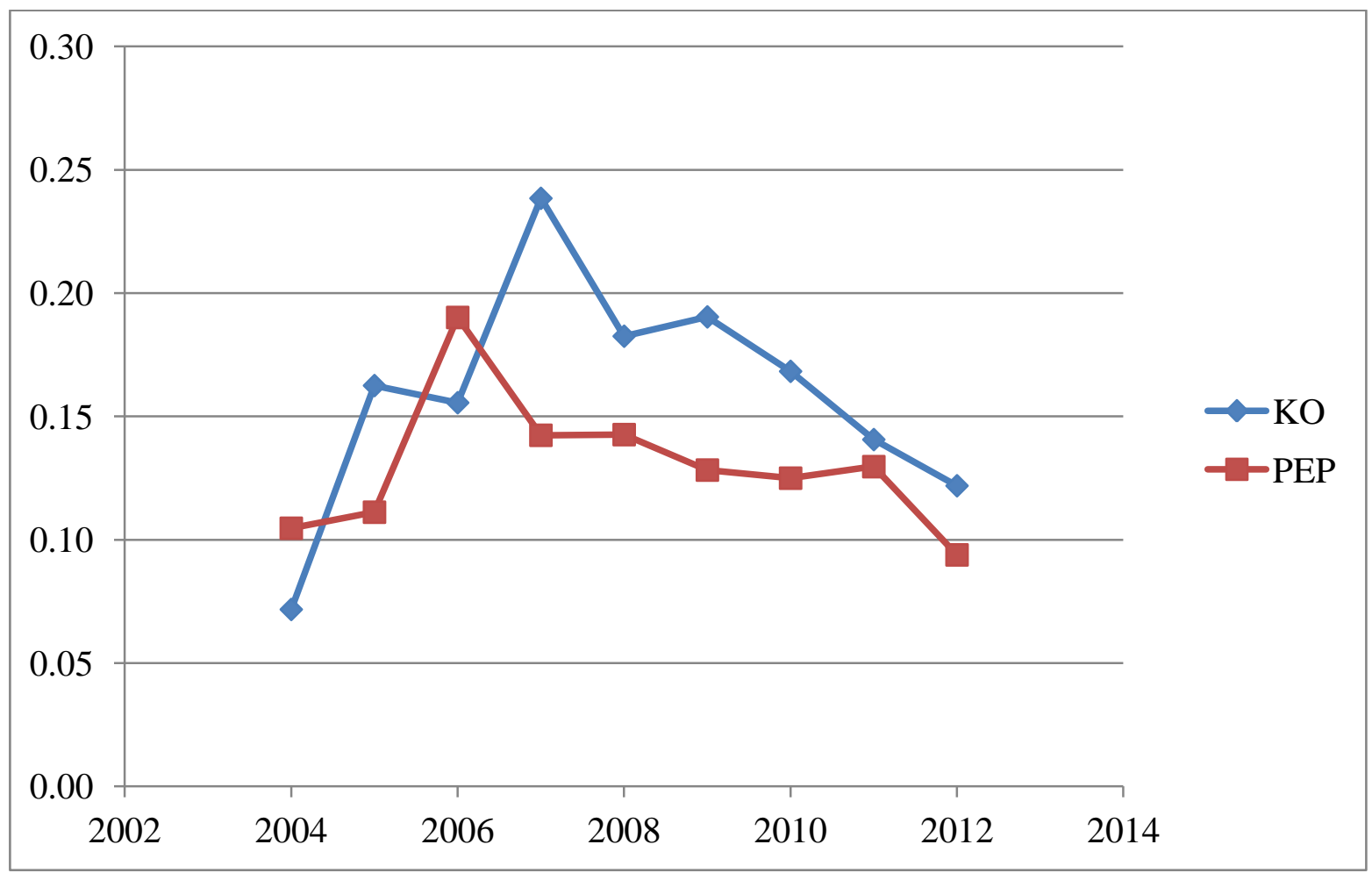

Figure 1: Business Betas for KO/PEP

\section{SUMMARY AND CONCLUSIONS}

The equity beta for a company is determined by the business risk, operating risk, and financial risk of the company. In this paper, we show how to adjust the equity beta for financial risk and operating risk to determine the business risk for the company. We apply the theory developed in this paper to Coca-Cola and Pepsico, the two largest companies in the soft drink industry, for the period from 2004-2012. The average business beta for CocaCola is 0.1882 and the average business beta for Pepsico is 0.1369 . Over the period of this analysis, Coca-Cola has had a business beta slightly higher than the business beta for Pepsico.

\section{DISCUSSION QUESTIONS}

1. What are the determinants of corporate value?

2. What are the determinants of equity beta?

3. Which company has the higher business beta and why?

\section{AUTHOR INFORMATION}

V. Reddy Dondeti earned his Ph.D. in Operations Research from Case Western Reserve University, Cleveland, Ohio, in 1986. He is currently a Professor in the School of Business at Norfolk State University, Norfolk, VA, and teaches courses in the areas of Decision Sciences and Finance. Prior to joining NSU (in August, 1989), he worked at companies such as Standard Oil of Ohio and AT\&T Bell Labs for more than 10 years. He has published several articles in different journals including Operations Research and the European Journal of Operational Research. Email: vrdondeti@nsu.edu 
Carl B. McGowan, Jr., PhD, CFA is a Faculty Distinguished Professor and Professor of Finance at Norfolk State University. His research is in the areas of corporate and international finance. He has published 85 articles and 101 proceedings and presented 175 papers at conferences. He has published in Applied Financial Economics, Decision Science, Financial Practice and Education, Journal of Economic and Financial Education, Financial Review, International Review of Financial Analysis, Journal of Applied Business Research, Journal of Business Case Studies, Journal of Real Estate Research, Managerial Finance, Managing Global Transitions, Multinational Business Review, and Urban Studies. E-mail: cbmcgowan@nsu.edu (Corresponding author)

Susan E. Moeller is a Professor of Finance at Eastern Michigan University. Prior to joining EMU, Dr. Moeller taught at Northeastern University and the University of Michigan - Flint. Her corporate experience was with Ford Motor Company. She has published in: Journal of Economic and Financial Education, Journal of Business Case Studies, Journal of Global Business, Journal of International Finance, Journal of Financial and Strategic Decisions, Management International Review, Journal of Applied Business Research, and AAII Journal. E-mail: smoeller@emich.edu

\section{REFERENCES}

1. Brigham, E. F., \& Ehrhardt, M. C. (2008). Financial management, theory and practice (Twelfth Edition). Mason, OH: Thomson/Southwestern.

2. Damodaran, A. (2006). Applied corporate finance (Second Edition). John Wiley \& Sons, Inc.

3. Gardner, J. C., McGowan, C. B., Jr., \& Moeller, S. E. (2010). Calculating the beta coefficient and required rate of return for Coca-Cola. Journal of Business Case Studies, 6(6), 77-83.

4. Hamada, R. S. (1969). Portfolio analysis, market equilibrium, and corporation finance. Journal of Finance, 24(1), 13-31.

5. Harper, N., Jordan, K., McGowan, C. B., Jr., \& Revello, B. J. (2010). Using hyperlinks to create a lecture on calculating beta and the required rate of return for dow chemical company. Journal of Business Case Studies, 6(6), 103-109.

6. 2010 Ibbotson Stocks, Bonds, Bills, and Inflation Valuation Yearbook (2010). Morningstar.

7. Markowitz, H. (1952). Portfolio selection. The Journal of Finance, 7(1), 77-91.

8. Ross, S. A., Westerfield, R. W., \& Jordan, B. D. (2008). Fundamentals of corporate finance (Eighth Edition). New York: McGraw-Hill Irwin.

9. Sharpe, W. F. (1963). A simplified model for portfolio analysis. Management Science, 9(2), 277-293.

10. Sharpe, W. F. (1964). Capital asset prices: A theory of market equilibrium under conditions of risk. Journal of Finance, 19(3), 425-552. 